\title{
Clinical aspects of syringocystadenoma papilliferum
}

\section{Mariem Mohamed ${ }^{1}$, Hichem Belhadjali' ${ }^{1}$ Rim Hadhri², Monia Youssef ${ }^{1}$, Jameleddine Zili ${ }^{1}$}

\author{
${ }^{1}$ Department of Dermatology, Fattouma Bourguiba University Hospital, Monastir, Tunisia, ${ }^{2}$ Department of Pathology, \\ Fattouma Bourguiba University Hospital, Monastir, Tunisia
}

Corresponding author: Dr. Mariem Mohamed, E-mail: mariemmohamed79@yahoo.fr

Syringocystadenoma papilliferum (SP) is a rare benign adnexal tumour which originates from the apocrine or the eccrine sweat glands. It usually appears at birth (50\% of cases) or during infancy around the time of puberty (15\%-30\% of cases) [1]. Three clinical types are described taking into consideration the appearance and localization of the tumor: the plaque type which presents as a hairless area on the scalp, is commonly associated with a sebaceous nevus of Jadassohn, the linear type with multiple reddish firm papules or umbilicated nodules which are usually seen in the face and neck region and the solitary nodular type which shows predilection for the trunk. Histological features are characteristic showing cystic cavities filled with irregular villosities lined by two rows of epithelial cells; one made of luminal cylindrical cells with decapitation secretions, the other composed of basal cuboidal cells. Within the stroma, a dense plasma cell infiltrate is classically present [2]. Various malignancies like basal cell carcinoma, squamous cell carcinoma and ductal carcinoma have been documented to arise in SP [3].

We report two cases presenting two clinical forms of SP. The cases were consisted on a 59-year-old woman and an 8-year-old boy. The woman was presented with unique erythematous nodular tumor measuring $0.5 \mathrm{~cm}$ in diameter, with a sessile base and an ulcerated crusty surface, located on the face (Fig. la), and evolved for ten years. The infant presented with three contiguous nodules on the neck (Fig. lb), evolving since the age of 2 years. The functional complaint was essentially infection and intermittent seepage in addition to esthetic discomfort. Histological examination of skin biopsy confirmed the diagnosis of SP in the 2 cases (Fig. 2a and b). Due to the risk of a malignant change, a wide surgical excision was proposed for the 2 patients, and no recurrence has been noted after a mean follow-up of 6 years.

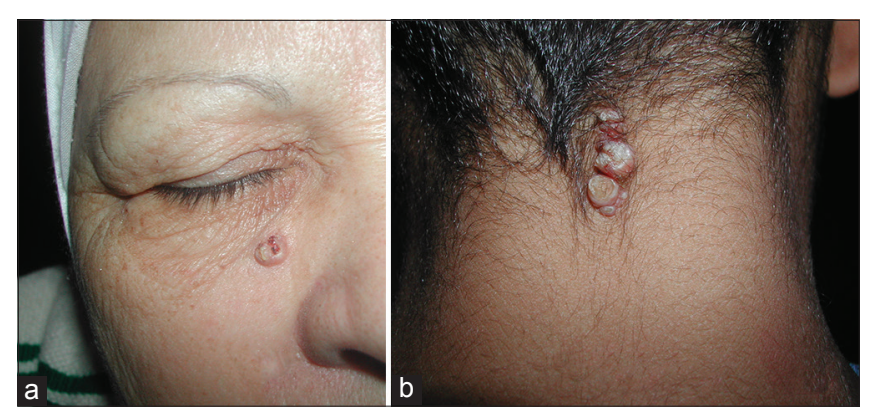

Figure 1: a) $0.5 \mathrm{~cm}$ in diameter, unique erythematous nodular tumor with a sessile base and an ulcerated crusty surface, located on the face, b) three linear reddish and well-shaped nodules on the neck.

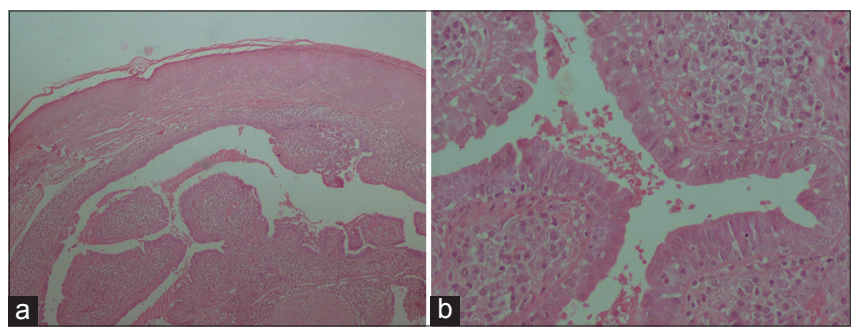

Figure 2: a) Epidermis shows papillomatosis. Cystic invagination extends downward from the epidermis (H\&E X40), b) cystic cavities filled with irregular villosities lined by two rows of epithelial cells (H\&E X100).

\section{REFERENCES}

1. Sangma MMB, Dasiah SD, Bhat V R. Syringocystadenoma Papilliferum of the Scalp in an Adult Male - A Case Report. J Clin Diagc Res. 2013;7:742-3.

2. Katoulis AC, Bozi E. Syringocystadenoma papilliferum. Orphanet Encyclopedia. April. 2004.

3. Hu Gel H, Reguena L. Ductal carcinoma arising from a syringocystadenoma papilliferum in a nevus sebaceous of Jadassohn. Am J Dermatopathol. 2003;23:490-93.

Copyright by Mariem Mohamed, et al. This is an open-access article distributed under the terms of the Creative Commons Attribution License, which permits unrestricted use, distribution, and reproduction in any medium, provided the original author and source are credited. Source of Support: Nil, Conflict of Interest: None declared.

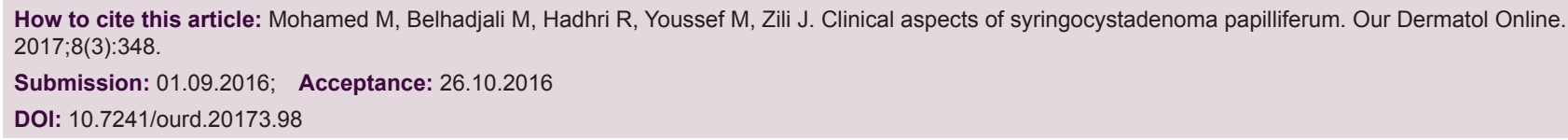

